\title{
Autologous cord blood harvesting in North Eastern Italy: ethical questions and emerging hopes for curing diabetes and celiac disease
}

This article was published in the following Dove Press journal:

International Journal of General Medicine

14 June 2012

Number of times this article has been viewed

\section{Sergio Parco \\ Fulvia Vascotto \\ Institute for Maternal and Child Health, IRCCS Burlo Garofolo, \\ Trieste, Italy}

Video abstract

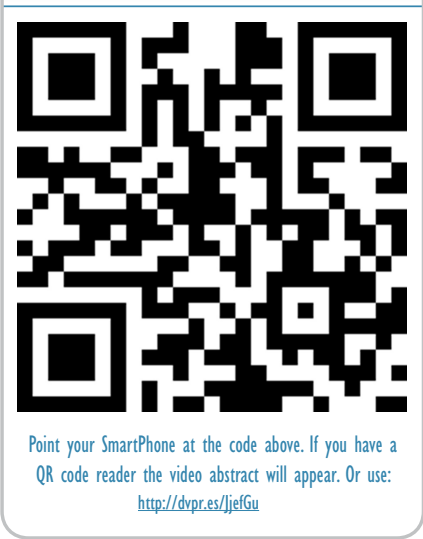

Correspondence: Sergio Parco Institute for Maternal and Child Health, Via dell'Istria 65/I, 34I37, Trieste, Italy Tel $+39(040) 3785332$

Fax +39 (040) 3785210

Email parco@burlo.trieste.it
Background: The Friuli Venezia Giulia (FVG), a region of North Eastern Italy, has passed legislation (Decree No 2324/2010) to regulate the banking of umbilical cord blood samples for personal, autologous, or family-directed use, and to implement the Agreement of the State-Regions Permanent Conference (Decree No 62/CSR/2010). This paper aims to identify the formalities and the reasons why families collect and bank their cord blood in foreign banks for both personal and private use.

Methods: To this end, at the Institute for Maternal and Child Health of Trieste (the regional capital city of the FVG), Italy, which assists about 1800 pregnant women a year, 129 questionnaires, drafted from January 2010 to December 2011 and concerning the granting of authorization to export samples, were examined.

Results: The collected data showed that $75 \%$ of involved families had resorted to anonymous public collection, which is available to anyone with therapeutic needs, and provided compatibility and hematologic protocols recognized by the scientific and international community (main indications: leukemia, hemoglobinopaties, and inherited hematologic and immunologic disorders). Conversely, $25.0 \%$ requested private storage at a foreign bank for personal or family-dedicated use. The principal motivation by disease was for treatment for diabetes $(22.4 \%)$ and celiac disease (19.7\%) (a multiorgan disease for which the FVG region has provided safeguards by approving a specific law granting support to families; Decree No 561/2007). For these two types of disease we found that information was received from the internet and not from general medical physicians, with a significant difference found using the $\chi^{2}$ test $(P<0.01)$.

Conclusion: The indication of treating these diseases with cord blood stem cell transplantation appears to be well grounded and encouraging, and has recently been corroborated by the international literature; however, the economic and social motivations promoting cord blood storage, for a fee, in the event of diseases that are still under study, require accurate information through general medical physicians on the actual possibilities of treatment.

Keywords: autologous cord blood harvesting, North Eastern Italy, emerging hopes of therapy

\section{Introduction}

Ever since the first cord blood stem cell (CB-SC) transplantation, ${ }^{1}$ placental blood collection has been playing a major role as a source of hematopoietic SCs, acquiring fundamental importance in clinical practice. ${ }^{1-6}$ The evidence that the SCs contained in the CB-SCs could offer, at least in children, a viable alternative to bone marrow transplantation from a donor's bone marrow blood, which until then was used in allogeneic bone marrow transplants, opened new therapeutic prospects. This led to the 
creation, throughout Europe, of public banks for the cryopreservation of CB-SC bags from homologous donations for allogeneic use. With the possibility of generating neural, pancreatic, and cardiac tissues from human progenitor cells, and the in vitro differentiation of the derived multipotent cells, the problem of collecting and storing at a private bank the CB-SCs from homologous donation for autologous or family-dedicated use is now being proposed. ${ }^{7-9}$ Allogeneic use is now consolidated and documented by the international scientific literature; however, the scientific literature regarding collection for autologous use has not been documented to the same extent..$^{10-12}$

\section{New therapies for celiac disease, diabetes, cystic fibrosis, and other pathologies}

Autologous SC transplantation is also becoming an increasingly interesting and effective therapeutic option for autoimmune diseases such as refractory celiac disease, which affects a small proporation $(2 \%-5 \%)$ of patients with a celiac disease diagnosis who continue to present with bowel lesions despite a gluten-free diet. ${ }^{13}$ The rationale that is frequently offered in favor of placental blood storage programs consists of the hypothesis that, in the future, therapeutic programs will be developed for tissue repair (eg, heart, nervous system, and liver). Thus, patients who have their own SCs available will have greater chances of recovery than patients who have not preserved them, even in many years' time. ${ }^{14}$

SC transplantation is also a subject of study for the cure of type 1 diabetes (T1D), a disease affecting 3\% of the population in Italy. In this field, to avoid risks of rejection, it is advisable to use adult autologous SCs harvested from the patient himself/herself. ${ }^{15}$ However, this therapy is not likely to be effective for long-term treatment of T1D, and recent studies suggest that alternative approaches using human CB-SCs and mesenchymal stem cells have been shown to modulate immune activity in vitro. ${ }^{16-18}$ These initial results indicate that $\mathrm{CB}-\mathrm{SCs}$ may have important implications for other autoimmune, neurologic, and inflammation-related diseases. ${ }^{19-21}$

The absence of confirmed scientific data and medical trials confirming the possibility of specific therapies for diabetes mellitus and celiac disease, including the transplantation of autologous CB-SCs, and the lack of evidence supporting the integrity and function of cord cells after decades have not stopped the growing storage requests. The recent nuclear disaster of Fukushima, Japan, has influenced the public even more and increased private autologous collection for future therapies with $\mathrm{CB}-\mathrm{CSs}{ }^{22}$

\section{The Italian legislation}

In Italy, CB-SC storage is exclusively allowed at authorized public facilities (about 15 of them are scattered across the country) and is envisaged either for solidarity purposes (ie, for any patient requiring it, without any discrimination) or for an ad hoc use (donation targeted at a family member affected by a disease and requiring a transplant, and in the case of families at high risk of genetic diseases that are curable by hematopoietic SC transplantation). However, CB-SC storage for autologous use reserved for the donor (who is healthy at the time of birth and is highly likely never to need his/her cord blood) is not allowed. The Italian legislation explicitly forbids private facilities not only to store CB but also to advertise and promote such an activity (ordinance by the Ministry of Health on February 26, 2009).

The ordinance, however, allows women who want to preserve their CB for their child to do so, for a fee, at accredited foreign banks, subject to a previous authorization by the Ministry of Health. In compliance with the Italian national legislation, the Friuli Venezia Giulia (FVG) region of North Eastern Italy has regulated CB-SC collection, transport, and storage. It has identified the Institute for Maternal and Child Health of Trieste (the regional capital city) as the center responsible for the regional public collection program, and the Cord Blood Bank of Padua (a city located in the neighbouring Veneto region) as the storage center, by means of an operational transport protocol entrusted to the civil protection volunteers. Furthermore, the FVG region has entrusted the health care boards of birth centers with the responsibility of granting authorization for the banking of CB-SCs in foreign states for private use, by establishing a fee to cover collection costs $(€ 300)$ to be added to the approximately $€ 2000$ a year charged by the foreign bank (Decree No 2324/2010).

\section{Aim}

Therapies for autoimmune diseases such as diabetes and celiac disease are still under study and often create false expectations as they still require further scientific evidence.

The aim of this paper is to evaluate the questionnaires submitted to the health care board of the Institute for Maternal and Child Health of Trieste, for the private collection of CB-SCs during the 2010-2011 period, to identify the formalities and the reasons why families collect and bank their cord blood in foreign banks, for both personal and private use, 
and in order to study and prepare for an update meeting with the general practitioners (GPs) and specialist physicians of the FVG region on the actual possibilities of treatment with autologous CB-SCs and the information that the mass media give to pregnant women regarding the storage and therapeutic use of CB-SCs.

\section{Patients and methods}

Approximately 1800 deliveries take place at the Institute for Maternal and Child Health every year. In the years 2010-2011, 386 applications were submitted for collection and storage at a public CB-SC bank and 129 applications for private collection. Of these 129, the examined questionnaires, which had been approved by the bioethical committee of the institute, were filled out during the interview with the health care board physician for the granting of authorization to export to a foreign bank. The interview was confidential and took place after confirmation tests were performed and information on the pregnancy provided, as requested by the general medical physician (GM). In addition to including the regulations for $\mathrm{CB}-\mathrm{SC}$ collection and storage issued by the FVG region, the questionnaire specified the bank where samples were to be sent, the collection and storage methods certified according to the European Community regulations, as well as the possibility of noncollection in the event of premature births or bacterial contamination, the date of the delivery, manner of transport, country of destination, and presence of genetically determined disease in the family (Figure 1). ${ }^{31}$ Once both parents had given their consent and the required certifications (sent to the family by the foreign bank where the deposit was to be made), the health care board physician issued the authorization and thoroughly explained the possible therapies, for final approval by both parents. Every 6 months, data were collected and sent to the central health directorate of the FVG region and the Ministry of Health. The data and the information about the two pathologies (diabetes and cystic fibrosis) were studied with a $\chi^{2}$ test to determine whether the two groups had significant differences of information source (internet or GM) and were applied to cross-tabulations.

\section{Results}

From January 2011 to December 2012, a total of 3650 deliveries took place at the Institute for Maternal and Child Health. A total of $25.0 \%$ of these mothers did not choose public, anonymous collection for solidarity and therapeutic purposes, which is approved by the European regulations, but instead chose private use. In total, 129 families (two of which were from neighboring countries, Slovenia and Austria) applied for private collection at a foreign nonpublic bank (Table 1). The most frequent motivations concerned the general possibility of storage for personal use (84), excluding donations to subjects outside the family without particular therapeutic needs. Information and news on CB-SC collection had been supplied by the internet $(78.29 \%)$ or by gynecologists $(5.42 \%)$, nurses $(3.87 \%)$, friends and family members $(2.32 \%)$, hematologists $(0.77 \%)$, volunteer associations $(0.77 \%)$, or the media $(0.77 \%)$. Only ten pregnant women $(7.75 \%)$ had received information from their GPs on

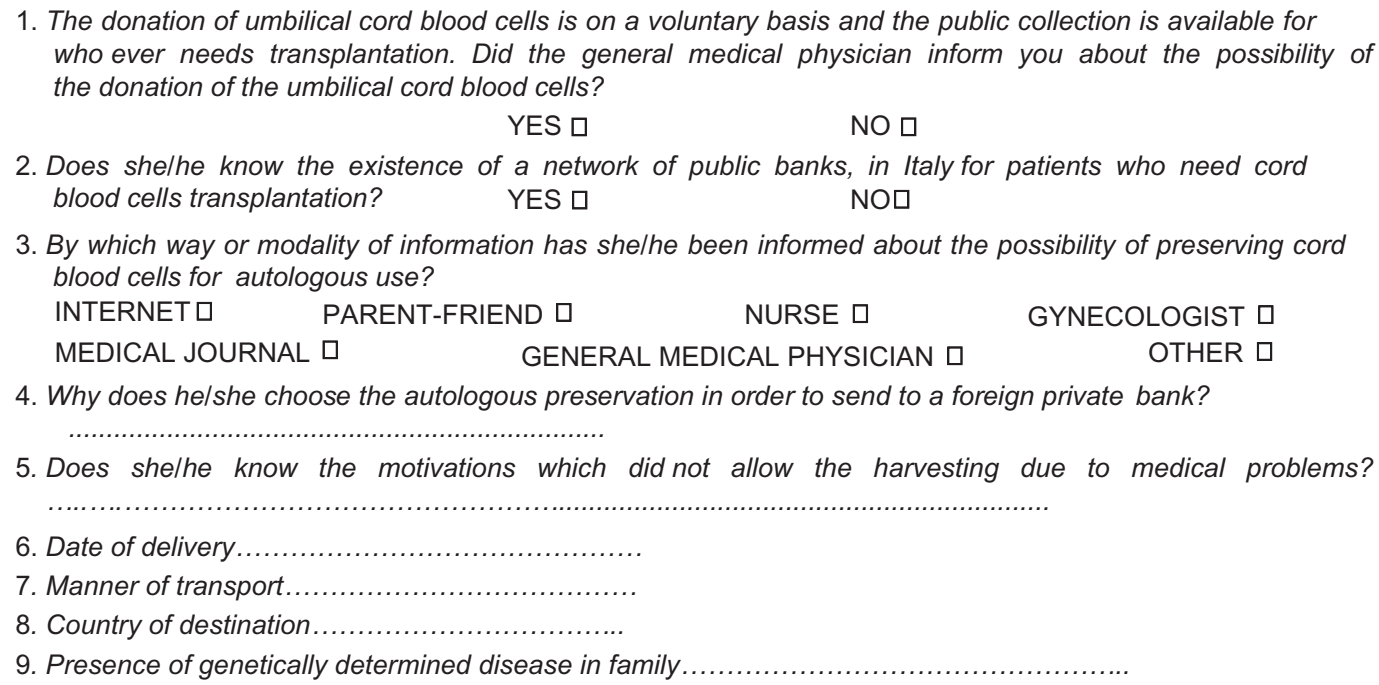

Figure I Private family questionnaire (translated). 
Table I Foreign country of autologous cord blood destination

\begin{tabular}{lll}
\hline Foreign country & Total number & $\%$ \\
\hline Switzerland & 38 & 29.4 \\
Germany & 30 & 23.2 \\
England & 28 & 21.7 \\
St Marino Republic & 25 & 3.1 \\
Poland & 4 & 2.3 \\
Slovakia & 3 & 2.3 \\
Belgium & 1 & 0.8 \\
\hline
\end{tabular}

the possibility of collecting CB-SCs, and of these everybody had forgotten private collection to opt for public collection (Table 2). Among the prevailing motivations was the hope of curing diabetes $(22.4 \%)$ and celiac disease (19.3\%) (a multiorgan disease for which the FVG region has provided safeguards by approving specific legislation to support families [Decree No 561/2007]), then cystic fibrosis (17.8\%), Alzheimer's disease (17.0\%), cardiovascular diseases (2.0\%), and other pathologies. For the first two groups of diseases, information was supplied by the internet and not by GPs $(P<0.01)$ (Table 3).

Families who during pregnancy had turned to their GPs stated that they were not given precise and thorough information on the existence of transplantation therapies for diabetic and other diseases; some families had asked, without obtaining it, for information on the therapies for celiac disease by which they were affected. This condition excluded them from public collection by law. The results show that GMs did not inform families about autologous CB harvesting and the therapeutic hematologic applications. The families did not receive information about the possibility of cure in future pathologies not yet included in the common international protocols. The answers were described as evasive and incomplete, and ranged from a concrete possibility of therapy to exclusion. Information obtained from the internet was prevalent. That happens because these issues are more often described than others and marketing is prevalent by private banks. The importance and the relevant social cost of curing

Table 2 Type of information

\begin{tabular}{lll}
\hline Source & Total number & $\%$ \\
\hline General medical physician* & 10 & 7.76 \\
Gynecologist physician & 7 & 5.43 \\
Nurses & 5 & 3.88 \\
Parents/friends & 3 & 2.33 \\
Voluntary associations & $\mathrm{I}$ & 0.77 \\
Hematology physician & $\mathrm{I}$ & 0.77 \\
TV, journals, magazines, media & $\mathrm{I}$ & 0.77 \\
Internet* & $\mathrm{I} 0 \mathrm{I}$ & 78.29 \\
\hline
\end{tabular}

Note: $*$-value $<0.01$.
Table 3 Motivation for request for pathology

\begin{tabular}{lll}
\hline Pathology & Total number & $\%$ \\
\hline Diabetes & 29 & 22.4 \\
Celiac disease & 25 & 19.3 \\
Cystic fibrosis & 23 & 17.8 \\
Alzheimer's disease & 22 & 17.0 \\
Cardiovascular disease & 11 & 8.5 \\
Hematology disease & 10 & 7.7 \\
Other & 9 & 6.9 \\
\hline
\end{tabular}

severe autoimmunity pathologies, such as refractory Crohn's disease, include medical support about pharmaceutical treatment and actual therapies. ${ }^{32}$

\section{Conclusion}

In Italy, public collection allows "... storage for an ad hoc use, for newborns affected by a disease at the time of collection or previously, for which the use of cord blood stem cells is scientifically grounded and clinically appropriate ... it is also allowed for an ad hoc use in the case of families at risk of having children affected by genetically determined diseases ... and/or ... also within the framework of clinical experimentations approved according to the existing legislation. ${ }^{.37}$ In these cases, samples are stored in public banks at the expense of the regional health care service.

In addition to this law, the possibility of preserving a sample for autologous use is currently allowed only at private facilities abroad, subject to authorization by the region of origin (ordinance of the Ministry of Health on February 26, 2009).

Around the world, the number of placental samples stored at private banks and for personal (autologous) use is three times larger than that of samples donated for public use. ${ }^{23}$ These procedures subvert the concept of a solidarity use for the collection of blood and its components, including SCs, and can considerably damage it. However, the psychological pressure exerted by the media on the radiation damage caused by the recent Japanese tsunami and the possibility of bone marrow and SC transplantation develops an emotional tension that is reminiscent of other nuclear tragedies, such as Hiroshima, Nagasaki, and, more recently, Chernobyl. Emotion, fear, and selfishness often prevail over the reasonableness of correct information and "counselling" to future parents, and families request the donation for autologous use in the hope of taking advantage, in the future, of treatments to cure diseases such as T1D, celiac disease, and other degenerative diseases with a high social impact, which have not yet been confirmed by clinical trials but only by experimental data. 


\section{Discussion}

GM and specialist physicians are called to deal with this topic with the awareness of being the first suppliers of information for the collection of CB-SCs, according to the program introduced by the FVG region and to specific international clinical protocols to treat leukemia, hemoglobinopaties, and immunologic disorders. Furthermore, international literature draws attention to the difficulties of autologous CB transplant in particular situations. For example, genetic alteration, already present in CB cells, makes CB use unsuitable for leukemia caused by chromosomal abnormalities; in the case of an autologous transplant, there is no beneficial "graft versus host leukemia" effect. ${ }^{24}$ With regard to public cord collection, the probability for donors to find, in case of need, their own placental blood units still available exceeds $97 \%$. $^{25,26}$ Furthermore, private collection discriminates between families who can afford it and families who cannot, thereby causing great damage to the cryopreservation of samples at public banks that are available to anyone needing them. ${ }^{27-29}$ The donations for private use do not always meet the same criteria of public storage (ie, number of cells, human T-cell lymphotropic virus type III). These differences among CB-CS units can lead to confusion about the curable pathologies by CB-CS disease.

The inclusion of placental blood collection into a specific program introduced by the National Health Service is of fundamental importance for future developments in this sector. The authors think the discussion should not be about banning private initiative to the advantage of State monopolies but about being able to get sufficient and effective means to treat future patients. This can be done successfully only through public-private collaboration..$^{30}$ This shows the added value of storage for potential use within the family, ie, for autologous and related allogeneic uses. ${ }^{33-36}$ To GMs goes the task of first providing the correct information on ethical themes and therapeutic possibilities, which are often incorrect and inappropriate, advertised by the media, often for money-making purposes, and without real evidence of confirmed efficacy.

\section{Disclosure}

The authors report no conflicts of interest in this work.

\section{References}

1. Gluckman E, Broxmeyer HE, Arleen D, Auerbach AD, Friedman HS, et al. Hematopoietic reconstitution in a patient with Fanconi's anemia by means of umbilical cord blood from an HLA identical sibling. $N E n g l$ J Med. 1989;321:1174-1178.

2. Vilmer E, Stenkers G, Rahimy C, et al. HLA-mismatched cord blood transplantation in a patient with advanced leukemia. Transplantation. 1992;53:1155-1167.
3. Bogdanovic V, Nemet D, Kastelan A, et al. Umbilical cord blood transplantation in a patient with Philadelphia chromosome positive chronic myeloid leukemia. Transplantation. 1993;56:477-479.

4. Vowels M, Lam Po Tang R, Berdoukas V, et al. Brief report: correction of X-linked lymphoproli ferative disease by transplantation of cord blood stem cells. N Engl J Med. 1993;329:1623-1625.

5. Kohli Kumar M, Shahidi N, Broxmeier H, et al. Haematopoietic stem/ progenitor cell transplant in Fanconi anaemia using HLA-matched sibling umbilical cord blood cells. Br J Haematol. 1993;85:419-422.

6. Issaragrisil S, Visuthisakchai V, Suvatte V, et al. Transpalntation of cord blood stem cells into a patient with severe thalassemia. $N$ Engl J Med. 1995;332:367-369.

7. Cord blood banking for potential future transplantation. American Accademy of Pediatrics policy statemen. Pediatrics. 2007;119:165-170.

8. American College of Obstetricians and Gynecologists. Umbilical cord blood banking. American College of Obstetricians and Gynecologists Committee Opinion No 399. Obstetr Gynecol. 2008;111:475-477.

9. American Society for Blood and Marrow Transplantation. Collection and preservation of cord blood for personal use. American Society for Blood and Marrow Transplantation. Committee report. Biol of Bone and Marrow Transplan. 2008;14:356-363.

10. Burgio GR, Gluckman E, Locatelli F, et al. Ethical reappraisal of 15 years of cord blood transplantation. Lancet. 2003;361:250-252.

11. Anjali J, Kaimal C, Smith C, Russel K, et al. Cost-effectiveness of private umbilical cord blood banking. Obstet Gynecol. 2009;114:848-855.

12. Austrian Bioethics Commission at the Federal Chancellery. Cord blood banking. May 19, 2008. Available at: http://www.bka.gv.at/DocView. axd?CobId=31001. Accessed April 27, 2012.

13. Al-toma A, Visser OJ, van Roessel HM, von Blomberg BM, Verbeek WH, Scholten PE, et al. Autologous hematopoietic stem cells transplantation in refractory celiac disease with aberrant T cells. Blood. 2007;1;109(5):2243-2249.

14. Uccelli A, Moretta L, Pistoia V. Mesenchymal stem cells in health and disease. Nat Rev Immunol. 2008;8:726-736.

15. Prabakar KR, Dominguez-Bendala J, Molano RD, Pileggi A, Villate S, et al. Generation of glucose-responsive, insulin-producing cells from human umbilical cord-derived mesenchymal stem cells. Cell Transpl. December 21, 2011. [Epub ahead of print.]

16. Mabed M. The potential utility of bone marrow or umbilical cord blood transplantation for the treatment of type 1 diabetes. Biol Blood Marrow Transplant. 2011;17:455-464.

17. Zhao Y, Lin B, Dingeldein M, Guo C, Hwang D, et al. New type of human blood stem cells: a double-edged sword for the treatment of type 1 diabetes. Transl Res. 2010;155:211-216.

18. Zhao Y, Jiang Z, Zhao T, et al. Reverse of type 1 diabetes via islet beta cell regeneration following immune modulation by cell blood-derived multipotent stem cells. BMC Medicine. 2012;10:3.

19. Wang G, Bunnel BA, Painter RG, Quiniones BC, Tom S, Lanson NA Jr, et al. Adult stem cells from bone marrow stroma differentiate into airway epithelial cells: potential therapy for cystic fibrosis. Pro Natl Acad Sci USA. 2005;4:186-191.

20. Lindvall O, Barker RA, Brüstle O, Isacson O, Svendsen CN. Clinical translation of stem cells in neurodegenerative disorders. Cell Stem Cell. 2012;10(2):151-155.

21. Strauer BE, Schannwell CM, Brehm M. Therapeutic potentials of stem cells in cardiac diseases. Minerva Cardioangiol. 2009;57(2):249-267.

22. Rosenthal J, Woolfrey AE, Pawloska A, et al. Haematopoietic cell transplantation with autologous cord blood in patients with severe aplastic anemia. An opportunity to revisit the controversy regarding cord blood banking private use. Pediatr Blood Cancer. 2011;7:1009-1012.

23. Gluckman E, Ruggeri A, Rocha V, Badoux E, Boo M, et al. Family-directed umbilical cord blood banking. Haematologica. 2011; 96(11):1700-1707.

24. Gluckman E, Rocha V, Boyer-Chammard A, et al. Outcome of cordblood transplantation from related and unrelated donors. Eurocord Transplant Group and the European Blood and Marrow Transplantation Group. N Engl J Med. 1997;337(6):373-381. 
25. Ballen KK, Barker JN, Stewart SK, Greene MF, Lane TA. Collection and preservation of cord blood for personal use. Transplantation. 2008; $14: 356-363$.

26. Spurr EE, Wiggins NE, Marsden KA, Lowenthal RM, Ragg SJ. Cryopreserved human haematopoietic stem cells engrafment potential after extended (5-14 years) cryostorage. Cryobiology. 2002;44: 210-217.

27. Petrini C. Umbilical cord blood collection, storage and use: ethical issues. Blood Transfus. 2010;8(3):139-148.

28. Manegold G, Meyer-Monard S, Tichelli A, Granado C, Hosli I, Troeger C. Controversies in hybrid banking: attitudes of Swiss public umbilical cord blood donors toward private and public banking. Arch Gynecol Obstet. 2011;284(1):99-104.

29. Rosenthal J, Woolfrey AE, Pawlowska A, Thomas SH, Appelbaum F, Forman S. Hematopoietic stem cell transplantation with autologous cord in patients with severe aplastic anemia. An opportunity to revisit the controversy regarding cord blood banking for private use. Pediatr Blood Cancer. 2011;56(7):1009-1112.

30. Fisk NM, Atun R. Public-private partnership in cord blood banking. Brit Med J. 2008;336(7645):642-644.

31. European Directorate for the Quality of Medicines and Health Care of the Council of Europe (EDOM). Guide to the preparation, use and quality assurance of blood components. Recommendation No R(95) 15.
32. Grawthol A, Baldomero H, Frauendorfer K, et al. Joint Accreditation Committee of the International Society for Cellular Therapy (ISCT); European Group for Blood and Marrow Transplantation EBMT (Jacie). The EBMT activity survey 2006 on hematopoietic stem cell transplantation. Bone Marrow Transplant. 2008;41(8):687-705.

33. Kreisel W, Potthoff H Bertz, et al. Complete remission of Crohn's disease after high-dose cyclophosphamide and autologous stem cell transplantation. Bone Marrow Transplantation. 2003;32:337-340.

34. Burt RK, Trainor A, Oyama Y, Creig R. High-dose immune suppression and autologous hematopoietic stem cell transplantation in refractory Crohn disease. Blood. 2003;101:2064-2066.

35. Rabusin M, Maximova N, Andolina M, Parco S, et al. Immunoablation followed by autologous hematopoietic stem cell infusion for the treatment of severe autoimmune disease. Haematologica. 2000;85(Suppl 11): 81-85.

36. Hawkey CJ, Snowden JA, Lobo A, et al. Stem cell transplantation for inflammatory bowel disease: practical and ethical issues. Gut. 2000;46: 869-872.

37. Petrini C, Farisco M. Informed consent for cord blood donation. A theoretical and empirical study. Blood Transfusion. 2011; July, 9(3): $292-300$.

\section{Publish your work in this journal}

The International Journal of General Medicine is an international, peer-reviewed open-access journal that focuses on general and internal medicine, pathogenesis, epidemiology, diagnosis, monitoring and treatment protocols. The journal is characterized by the rapid reporting of reviews, original research and clinical studies across all disease areas.
A key focus is the elucidation of disease processes and management protocols resulting in improved outcomes for the patient. The manuscript management system is completely online and includes a very quick and fair peer-review system. Visit http://www.dovepress.com/ testimonials.php to read real quotes from published authors. 